Volume 11 Number 1 May 2021 Page. 51-58

Journal Homepage : http://teknois.stikombinaniaga.ac.id/index.php/JBS

DOI Link : http://doi.org/10.36350/jbs.v11i1

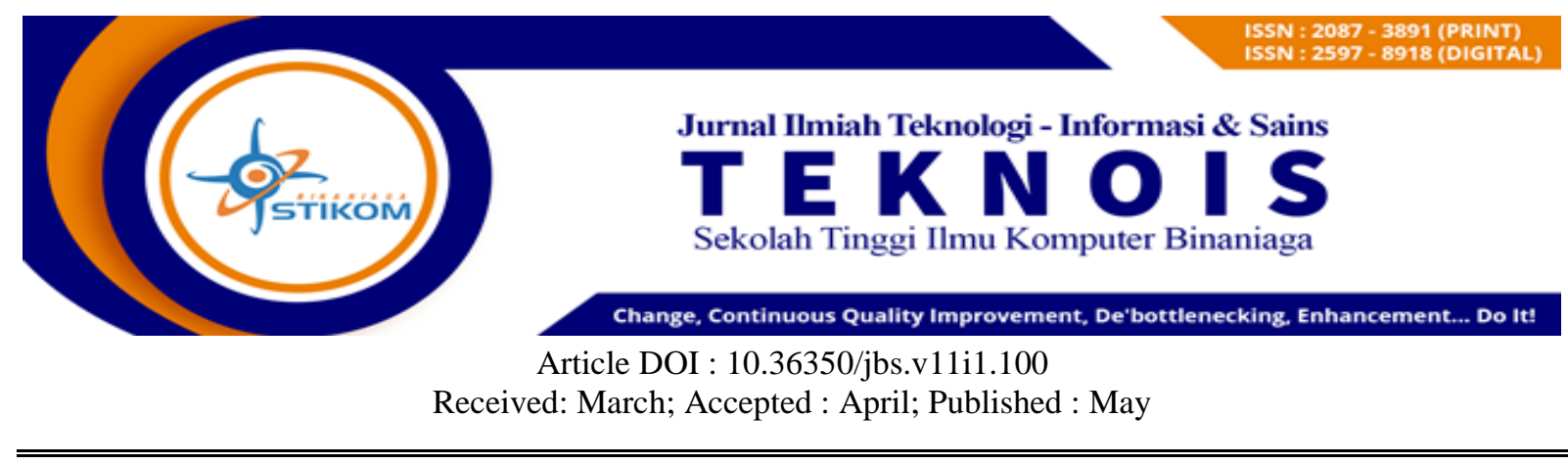

\title{
Penerapan Simple Additive Weighting Dalam Pemilihan Jenis Simpanan Untuk Calon Nasabah
}

\author{
Adiat Pariddudin $^{1^{*}}$, Cindy Cesilya ${ }^{2}$ \\ ${ }^{1}$ Sistem Informasi/STIKOM Binaniga \\ Email: adiat@stikombinaniaga.ac.id \\ ${ }^{2}$ Sistem Informasi/STIKOM Binaniga \\ Email: cindycesilya@gmail.com
}

\begin{abstract}
In the decision-making process that involves several criteria and alternatives, the Simple Additive Weighting (SAW) method is often used as a problem-solving method. Decision making is done by giving weight to each criterion. The criteria used are age, occupation, income and purpose of opening an account. These criteria are what influence decision making. The problem that occurs in determining the decision to choose the best deposit product is that many customers of Bank BNI KCP Pertamina Pusat do not know and are not precise in choosing the type of deposit product to be used. To reduce this inaccuracy, it is necessary to design a decision support system in selecting the best type of savings for prospective customers using the SAW (Simple Additive Weighting) Method because the SAW method is one of the decisions to assess each alternative or predetermined criteria. The results of this assessment are obtained from the top ranking with priority consisting of 4 (four) criteria and sub criteria so that the creation of an adequate Decision Support System (DSS) can help customer service officers in selecting the best savings products for prospective customers of the BNI KCP Pertamina Pusat bank. . The conclusion of this study shows that there are significant changes before development with after development, because it is able to provide accurate decision results.
\end{abstract}

Keywords: savings products, development, customer, accurate, SAW.

\section{ABSTRAK}

Dalam Proses pengambilan keputusan yang melibatkan beberapa kriteria dan alternatif, metode Simple Additive Weighting (SAW) sering digunakan sebagai metode pemecahan permasalahan. Pengambilan keputusan dilakukan dengan memberikan bobot pada setiap kriteria. Kriteria yang digunakan yaitu usia, pekerjaan, pendapatan dan tujuan pembukaan rekening. Kriteria - kriteria inilah yang berpengaruh dalam pengambilan keputusan. Permasalahan yang terjadi dalam penentuan keputusan pemilihan produk simpanan terbaik yaitu banyak nasabah Bank BNI KCP Pertamina Pusat yang belum mengetahui dan kurang tepat dalam pemilihan jenis produk simpanan yang akan digunakan. Untuk mengurangi ketidaktepatan tersebut maka perlu dirancang sebuah sistem pendukung keputusan dalam pemilihan jenis simpanan terbaik bagi calon nasabah menggunakan Metode SAW (Simple Additive Weighting) karena metode SAW ini merupakan salah satu keputusan untuk melakukan penilaian setiap alternatif atau kriteria yang telah ditentukan sebelumnya. Hasil dari penilaian ini diperoleh hasil dari peringkat teratas dengan prioritas terdiri dari 4 (empat) kriteria dan sub kriteria sehingga terciptanya Decision Support System (DSS) yang memadai dan dapat membantu petugas customer service dalam memilihkan produk simpanan terbaik untuk calon nasabah bank BNI KCP Pertamina Pusat. Kesimpulannya penelitian ini menunjukkan bahwa adanya perubahan yang signifikan pada sebelum pengembangan dengan sesudah pengembangan, karena mampu memberikan hasil keputusan yang akurat. 
Keywords: Produk simpanan, pengembangan, nasabah, akurat, SAW.

\section{A. PENDAHULUAN}

\section{Latar Belakang}

Peranan bank sangatlah penting bagi perekonomian suatu negara dalam hal mendukung pembangunan, karena pembangunan ekonomi di suatu negara sangat bergantung kepada dinamika perkembangan dan kontribusi nyata dari sektor perbankan. Perbankan merupakan industri jasa yang penting dalam menunjang pembiayaan pembangunan, baik sebagai penghimpun dana, sebagai lembaga yang memperlancar arus uang dari masyarakat dan menuju masyarakat. Dalam hal ini bank merupakan perantara keuangan masyarakat dan sebagai agen pembangunan.

Seiring dengan perkembangan teknologi banyak cara yang dirasa lebih praktis dan aman. Seperti menyimpannya di bank baik bank nasional maupun swasta. Biasanya bank berlomba lomba menarik calon nasabah dengan banyaknya penawaran-penawaran menarik dengan keuntungan yang sangat menggiurkan. Salah satunya adalah Bank Negara Indonesia atau BNI yang merupakan sebuah institusi bank milik pemerintah, dalam hal ini adalah perusahaan BUMN, di Indonesia.

Namun tidak semua calon nasabah tahu jenis-jenis simpanan apa saja yang sesuai dengan kebutuhan. Customer Service sudah memberikan informasi mengenai produk- produk yang ada di BNI secara jelas agar mempermudah nasabah dalam menentukan pilihan, namun nasabah banyak yang asal memilih, mendengarkan penjelasan namun sebenarnya belum mengerti dan hanya memiliki waktu yang singkat di bank, sehingga ini yang menjadi kendala nasabah salah dalam memilih produk simpanan yang sesuai dengan kebutuhannya.Ini mengakibatkan nasabah tidak mengetahui kerugian yang mungkin saja bisa didapatkan bila asal memilih jenis simpanan. Lebih dari itu tentunya calon nasabah akan merasa lebih nyaman menitipkan uang mereka di bank tersebut bila mereka mengetahui jenis simpanan terbaik yang bisa mereka dapatkan sesuai dengan kebutuhan dan kriteria yang diinginkan. Di BNI KCP Pertamina Pusat ini ditemukan saat nasabah datang mengeluhkan mengenai tabungannya yg biaya administrasi terlalu besar, atau limit yang dibutuhkan tidak sesuai padahal ini seharusnya bisa diminimalisir dari sejak awal pembukaan rekening. Kendala yang ditemukan lainnya adalah dari segi waktu customer service menjelaskan berbagai produk simpanan, yang seharusnya bisa langsung menjelaskan produk yang sesuai dengan kebutuhan nasabah sesuai kriteria.

Proses menentukan jenis simpanan terbaik berdasarkan banyak kriteria yang dinilai atau multikriteria, maka dalam penyelesaiannya diperlukan sistem pendukung keputusan multikriteria. Salah satu metode sistem pendukung keputusan yang multikriteria adalah metode Simple Additive Weighting (SAW). Metode SAW (Simple Additive Weighting) adalah salah satu metode yang digunakan untuk pengambilan keputusan. Metode SAW yang juga dikenal dengan metode penjumlahan berbobot. Konsep dasar metode SAW adalah mencari penjumlahan terbobot dari rating kinerja pada setiap alternatif pada semua atribut. Metode ini membutuhkan proses normalisasi matrix keputusan (x) ke suatu skala yang dapat diperbandingkan dengan semua rating alternatif yang ada.

\section{Permasalahan}

Bagi calon nasabah yang mengalami kesulitan dalam pemilihan produk simpanan terbaik yang sesuai dengan kebutuhan. Banyak nasabah yang sudah menggunakan produk namun merasa bahwa produk tidak sesuai dengan tujuan calon nasabah membuka rekening.

\section{Tujuan}

Menerapkan Metode SAW (Simple Additive Weighting) dalam pemilihan jenis simpanan terbaik bagi calon nasabah. 


\section{Tinjauan Pustaka}

Kusumadewi (2006:74) menyimpulkan bahwa Metode Simple Additive Weighting (SAW) sering dikenal juga dengan istilah metode penjumlahan terbobot. Konsep dasar metode SAW adalah mencari penjumlahan terbobot dari rating pada setiap alternatif pada semua atribut. Metode SAW membutuhkan proses normalisasi matriks keputusan (X) ke suatu skala yang dapat diperbandingkan dengan semua rating alternatif yang ada.

Formula untuk setiap alternatif (Vi) yaitu:

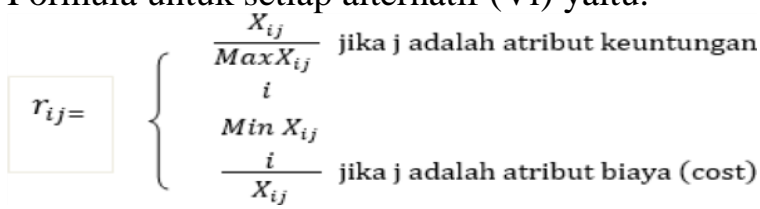

Dengan $r i j$ adalah rating kinerja ternormalisasi dari alternatif pada atribut $C ; i=1,2, \ldots \mathrm{m}$ dan $\mathrm{j}=1,2, \mathrm{n}$

Nilai preferensi untuk setiap alternatif $(V i)$ yaitu:

$$
V i=\sum_{j=1}^{n} W j r i j
$$

Nilai $V i$ yang lebih besar mengindikasikan bahwa alternatif $A i$ lebih terpilih.

Langkah dalam penyelesaian SAW yaitu:

a. Menentukan kriteria-kriteria yang akan dijadikan acuan dalam pengambilan keputusan, yaitu Ci.

b. Menentukan rating kecocokan setiap alternatif pada setiap kriteria.

c. Membuat matriks keputusan berdasarkan kriteria (Ci), kemudian melakukan normalisasi matriks berdasarkan persamaan yang disesuaikan dengan jenis.

\section{B. METODE}

SAW (Simple Additive Weighting) sering juga dikenal istilah metode penjumlahan terbobot. Konsep dasar metode SAW adalah mencari penjumlahan terbobot dari rating kinerja pada setiap alternatif pada semua atribut. Metode SAW membutuhkan proses normalisasi matriks keputusan (X) ke suatu skala yang dapat diperbandingkan dengan semua rating alternatif yang ada. Pada sistem keputusan pemilihan jenis simpan pada Bank BNI memiliki kriteria yaitu usia, pekerjaan, pendapatan dan tujuan pembukan rekening. Langkah-langkah penyelesaian metode SAW disajikan pada Gambar 1. Langkah - Langkah Penyelesaian SAW.

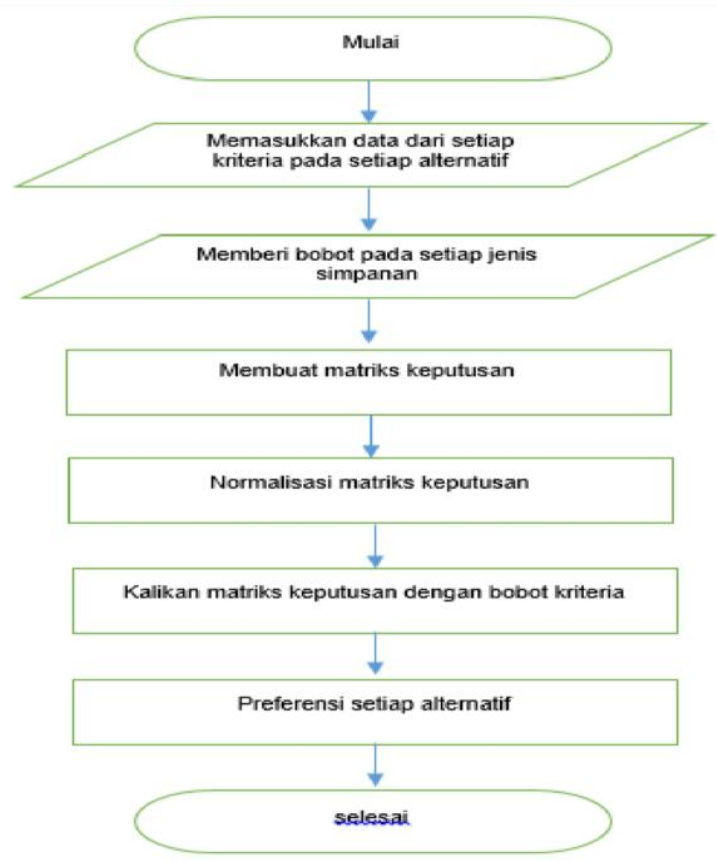

Gambar 1. Langkah-Langkah Penyelesaian SAW 


\section{HASIL DAN PEMBAHASAN}

\section{Hasil}

Hasil dari penerepan metode Simple Additive Weighting (SAW) dalam pemilihan jenis simpanan terbaik bagi calon nasabah yaitu, aplikasi prototype yang membantu merekomendasikan pemilihan jenis simpanan terbaik bagi calon nasaba. Kerieteria yang digunakan dan hasil rekomendasi yang diberikan disajikan pada Gambar 2. Keriteria Calon Nasabah dan Gambar 3. Hasil Rekomendasi Untuk Calon Nasabah

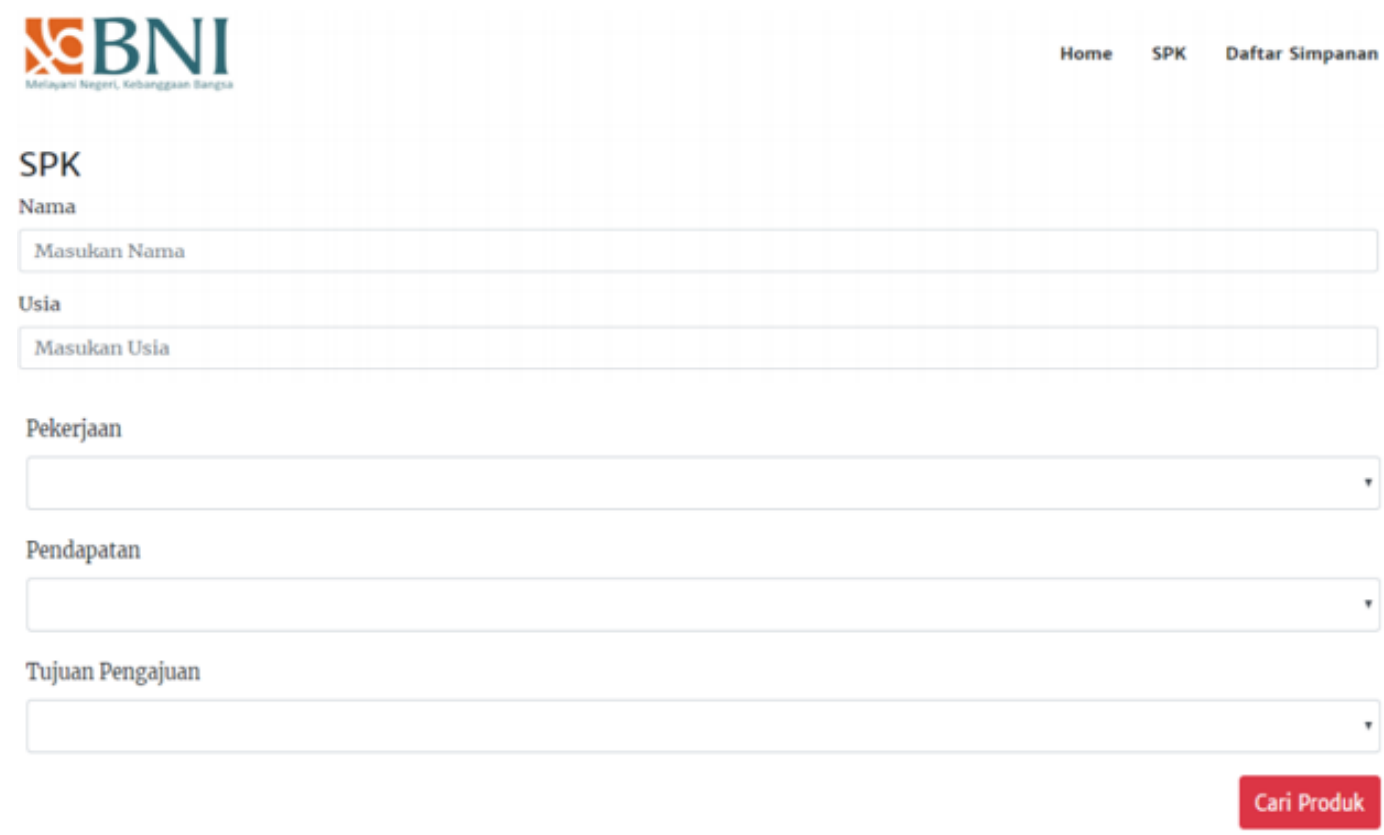

Gambar 3. Keriteria Calon Nasabah

$\sqrt{16 N I}$

Home SPK Daftar Simpanan

Data perhitungan yang sudah dilakukan, alternatit simpanan yang cocok dengan dera adalah:

\begin{tabular}{|c|c|c|c|c|c|c|}
\hline No & $\begin{array}{l}\text { Nama } \\
\text { Produk }\end{array}$ & Usia & Pekerjaan & Pendapatan & Tujuan Pengajuan & $\begin{array}{l}\text { Nilai } \\
\text { Saw }\end{array}$ \\
\hline 1 & $\begin{array}{l}\text { Taplus } \\
\text { Bisnis }\end{array}$ & $\begin{array}{l}17-35 \\
\text { Tahun }\end{array}$ & $\begin{array}{l}\text { Pengusaha, } \\
\text { Wiraswasta,Profesi }\end{array}$ & $\begin{array}{l}\text { Rp. } 20-< \\
100 \text { jt }\end{array}$ & $\begin{array}{l}\text { Simpanan/Tabungan sehari-hari memantau } \\
\text { aktivitas bisnis }\end{array}$ & 2.0549 \\
\hline 2 & Taplus & $\begin{array}{l}17-35 \\
\text { Tahun }\end{array}$ & $\begin{array}{l}\text { Karyawan Swasta, BUMN, } \\
\text { PNS, Guru }\end{array}$ & $\begin{array}{l}\text { Rp. } 5-<20 \\
\text { jt }\end{array}$ & $\begin{array}{l}\text { Simpanan/Tabungan sehari-hari belajar } \\
\text { menabung }\end{array}$ & 1.861 \\
\hline 3 & Tapenas & $\begin{array}{l}36-50 \\
\text { Tahun }\end{array}$ & $\begin{array}{l}\text { Karyawan Swasta, BUMN, } \\
\text { PNS, Guru }\end{array}$ & $\begin{array}{l}\text { Rp. } 5-<20 \\
\text { jt }\end{array}$ & Tabungan berjangka dan proteksi & 1.7375 \\
\hline 4 & Simponi & $\begin{array}{l}17-35 \\
\text { Tahun }\end{array}$ & $\begin{array}{l}\text { Mahasiswa,Ibu Rumah } \\
\text { Tangga }\end{array}$ & $\begin{array}{l}\text { Rp. } 5-<20 \\
\text { jt }\end{array}$ & Tabungan berjangka dan proteksi & 1.5775 \\
\hline
\end{tabular}

Gambar 4. Hasil Rekomendasi Untuk Calon Nasabah

\section{Pembahasan}

Dalam Metode Simple Additive Weighting (SAW) harus menentukan kriteria. Keriteria yang digunakan dalam penentuan produk simpanan terbaik terdiri dari 4 kriteria yaitu Usia, Pekerjaan, Pendapatan, dan tujuan. Setiap kriteria memiliki nilai bobot, selanjutnya matriks perbandingan antar kriteria dan hasil perhitungan matriks antara alternatif dengan kriteria. 
Volume 11 Number 1 May 2021 Page. 51-58

Journal Homepage : http://teknois.stikombinaniaga.ac.id/index.php/JBS

DOI Link : http://doi.org/10.36350/jbs.v11i1

Tabel 1. Kriteria

\begin{tabular}{|l|l|l|}
\hline No & Nama Kriteria & Kategori \\
\hline 1 & Usia 15\% & Benefit \\
\hline 2 & Pekerjaan 20\% & Benefit \\
\hline 3 & Pendapatan 35\% & Benefit \\
\hline 4 & Tujuan 30\% & Benefit \\
\hline
\end{tabular}

Tabel 2. Bobot Kriteria

\begin{tabular}{|c|c|}
\hline Range & Nilai Bobot \\
\hline $0-16$ Tahun & 0,25 \\
$17-35$ Tahun & 0,5 \\
$36-50$ Tahun & 0,75 \\
$51-70$ Tahun & 1 \\
\hline
\end{tabular}

Tabel 3. Bobot Kriteria Pekerjaan

\begin{tabular}{|c|c|}
\hline Range & Nilai Bobot \\
\hline Pelajar, Tidak Bekerja & 0,25 \\
\hline Mahasiswa, Ibu Rumah Tangga & 0,5 \\
\hline Swasta,BUMN,Guru, PNS & 0,75 \\
\hline Pengusaha, Wiraswasta profesi & 1 \\
\hline
\end{tabular}

Tabel 4. Bobot Kriteria Pendapatan

\begin{tabular}{|c|c|}
\hline Range & Nilai Bobot \\
\hline Rp. $<3 \mathrm{jt}$ & 0,2 \\
\hline Rp. $3 \mathrm{jt}-<5 \mathrm{jt}$ & 0,4 \\
\hline Rp. $5 \mathrm{jt}-<20 \mathrm{jt}$ & 0,6 \\
\hline Rp $20 \mathrm{jt}-100 \mathrm{jt}$ & 0,8 \\
\hline $\mathrm{Rp}>100 \mathrm{jt}$ & 1 \\
\hline
\end{tabular}

Tabel 5. Bobot Kriteria Tujuan

\begin{tabular}{|c|c|}
\hline Range & Nilai Bobot \\
\hline Simpanan, Simpanan Sehari-hari, Belajar Menabung & 0,8 \\
\hline Simpanan / Tabungan Sehari-hari, Tanpa Biaya Admin & 0,16 \\
\hline Memantau aktivitas Bisnis & 0,32 \\
\hline Tabungan Masa pensiun & 0,48 \\
\hline Investasi & 0,64 \\
\hline Tabungan Berjangka dan proteksi & 1 \\
\hline
\end{tabular}

Bank BNI KCP Pertamina Pusat sudah memiliki beberapa nasabah yang sudah mengambil simpan, untuk melihat apakah produk yang sudah di ambil. Dengan contoh sampel nasabah 
Volume 11 Number 1 May 2021 Page. 51-58

Journal Homepage : http://teknois.stikombinaniaga.ac.id/index.php/JBS

DOI Link : http://doi.org/10.36350/jbs.v11i1

adalah Nama yaitu Barry, Usia yaitu 63, Pekerjaan yaitu Karyawan Swasta, yaitu Pendapatan 10 (Jt), dan Produk Saat Ini yaitu Taplus.

Dalam data yang diambil contoh sampel yaitu Barry dengan usia 63 tahun, pekerjaan karyawan swasta, pendapatan $10 \mathrm{jt}$, masalah mengingikan tabungan di masa tua, dan produk saat ini adalah BNI Taplus. Maka disajikan pada Tabel 6. Nilai Bobot Kriteria Barry.

Tabel 6. Nilai Bobot Kriteria Barry

\begin{tabular}{|c|c|c|}
\hline \multicolumn{2}{|c|}{ Kriteria } & Nilai \\
\hline C1 & Usia & 1 \\
\hline C2 & Pekerjaan & 0,75 \\
\hline C3 & Pendapatan & 0,6 \\
\hline C4 & Tujuan & 0,48 \\
\hline
\end{tabular}

Pertama dilakukan normalisasi menjadi matriks untuk menghitung nilai masing - masing kriteria, menghitung berdasarkan kriteria keuntungan atau kriteria biaya dengan persamaan yaitu :

$$
R_{i}= \begin{cases}\frac{X_{i}}{M a x_{i} X_{i j}} & \text { (1) Jika } j \text { adalah atribut keuntungan (benefit) } \\ \frac{\operatorname{Min}_{i} X_{i j}}{X_{i}} & \text { (2) Jika j adalah atribut biaya (cost) }\end{cases}
$$

Rij = nilai rating kinerja ternormalisasi

Xij $\quad=$ nilai atribut yang dimiliki dari setiap kriteria

Maxi Xij = nilai terbesar aternatif dari setiap kriteria $\mathrm{i}$

Mini Xij = nilai terkecil alternatif dari setiap kriteria $\mathrm{i}$

benefit $\quad=$ jika nilai semakin besar semakin baik

cost $\quad=$ jika nilai semakin kecil semakin baik

a. Perhitungan kriteria Umur

$$
\mathrm{R}_{11}=\frac{1}{\operatorname{Max}\{1 ; 0,75 ; 0,75 ; 0,5 ; 0,75 ; 0,5\}}=\frac{1}{1}=1
$$

b. Perhitungan kriteria Pekerjaan

$$
\mathrm{R}_{11}=\frac{0,75}{\operatorname{Max}\{0,75 ; 1 ; 0,75 ; 0,5 ; 0,75 ; 0,75\}}=\frac{1}{1}=0,75
$$

c. Perhitungan kriteria Pendapatan

$$
\mathrm{R}_{11}=\frac{1}{\operatorname{Max}\{1 ; 0,8 ; 0,6 ; 0,2 ; 1 ; 0,6\}}=1
$$

d. Perhitungan kriteria Tujuan

$$
\mathrm{R}_{11}=\frac{0,64}{\operatorname{Max}\{0,64 ; 0,32 ; 0,8 ; 0,16 ; 0,5 ; 1\}}=0,64
$$

Kemudian matriks normalisasi yang sudah didapatkan per kriteria sebelumnya dihitung untuk mendapatkan alternatif yang terbaik. Tabel nilai matriks normalisasi disajikan pada tabel 7. Hasil Alternatif Normalisasi

Tabel 7. Hasil Alternatif Normalisasi

\begin{tabular}{|c|c|c|c|c|}
\hline Alernatif Kriteria & Usia & Pekerjaan & Pendapatan & Tujuan \\
\hline Deposito BNI Taplus & 1 & 0,75 & 1 & 0,64 \\
\hline Bisnis & 0,75 & 1 & 0,8 & 0,32 \\
\hline BNI Taplus & 0,75 & 0,75 & 0,6 & 0,8 \\
\hline Tabunganku & 0,5 & 0,5 & 0,2 & 0,16 \\
\hline
\end{tabular}


Volume 11 Number 1 May 2021 Page. 51-58

Journal Homepage : http://teknois.stikombinaniaga.ac.id/index.php/JBS

DOI Link : http://doi.org/10.36350/jbs.v11i1

\begin{tabular}{|c|c|c|c|c|}
\hline Simponi & 0,75 & 0,75 & 1 & 0,5 \\
\hline Tapenas & 0,5 & 0,75 & 0,6 & 1 \\
\hline
\end{tabular}
a. Deposito
$=\{(1 * 1)+(0,75 * 0,75)+(0,6 * 1)+(0,48 * 0,64)\}=2,469$
b. BNI Taplus Bisnis $=\{(1 * 0,75)+(0,75 * 1)+(0,6 * 0,8)+(0,48 * 0,32)\}=2,133$
c. BNI Taplus
$=\{(1 * 0,75)+(0,75 * 0,75)+(0,6 * 0,6)+(0,48 * 0,8)\}=2,0565$
d. Tabunganku
$=\left\{(1 * 0,5)+\left(0,75^{*} 0,5\right)+(0,6 * 0,2)+(0,48 * 0,16)\right\}=1,0718$
e. Simponi
$=\{(1 * 0,75)+(0,75 * 0,75)+(0,6 * 1)+(0,48 * 0,5)\}=2,1525$
f. Tapenas
$=\{(1 * 0,5)+(0,75 * 0,75)+(0,6 * 0,6)+(0,48 * 1)\}=1,9025$

Dari perhitungan, dapat disimpulkan bahwa alternatif yang sesuai dengan Barry sebagai produk terbaik adalah Deposito dengan perolehan nilai 2,469.

\section{KESIMPULAN}

Berdasarkan hasil penelitian yang telah diuraikan, maka kesimpulan yaitu:

1. Dengan menerapkan Metode SAW (Simple Additive Weighting) dalam pemilihan jenis simpanan terbaik. Calon nasabah dapat mendapatkan jenis tabungan yang terbaik untuk mereka.

2. Tersedianya prototype aplikasi untuk memrekomendasikan jenis tabungan yang terbaik untuk calon nasabah.

\section{E. DAFTAR PUSTAKA}

[1] Anhar. 2010. PHP \& MySql Secara Otodidak. Jakarta: PT TransMedia

[2] Arif .A, Nur .M.R, 2010, Dasar-dasar Pemasaran Bank Syariah, Bandung: Alfabeta

[3] Arikunto, Suharsimi. 2009. Prosedur Penelitian Suatu Pendekatan Praktik. Jakarta : Rineka Cipta.

[4] Connolly, T., Begg, C. 2010. Database Systems: a practical approach to design, implementation, and management. 5th Edition.America:Pearson Education.

[5] Hardiyan. 2019. "pendukung keputusan dalam penentuan produk terbaik pada pt. Asuransi jiwa generali”. Jurnal sisfikom, vol. 08, no. 1, maret 2019.

[6] Hartono, Bambang, SKM, MSc, MM. 2013. Sistem Informasi Manajemen Berbasis

[7] Jordie, m. 2018. "penerapan metode simple additive weighting dalam sistem pendukung keputusan pemilihan premier banking manager terbaik studi kasus : bank ocbc nisp cabang metro pondok indah". Skanika vol. 1, no 1. Maret 2018.

[8] Kusrini, (2007). Konsep dan Aplikasi Sistem Pendukung Keputusan,Andi, Yogyakarta.

[9] Kusumadewi, Sri. Purnomo, Hari., "Aplikasi Logika Fuzzy untuk Pendukung Keputusan".Yogyakarta: GRAHA ILMU,2006

[10] Lubis, Derman J., and Nur M. Fadil. "Penerapan Metode SAW (Simple Additive Weighting) untuk Menentukan Siswa Bermasalah di SMK Taruna Terpadu 2 Bogor." Teknois, vol. 10, no. 1, 4 May. 2020, pp. 35-44, doi:10.36350/jbs.v10i1.76.

[11] Nazrian, adli. 2012. "studi tentang keputusan nasabah dalam menabung di bank sumut cabang usu medan metode analytical hierarchy process". Usu medan.

[12] Pressman, Roger S. 2012.Rekayasa Perangkat Lunak (Terjemahan LN Hananingrum).

[13] Santoso, Cahyono B., and Dede Sunarya. "Penerapan Simple Additive Weighting dalam Penentuan Bonus Tahunan Karyawan Sekolah Alam Cikeas." Teknois, vol. 10, no. 1, May. 
Volume 11 Number 1 May 2021 Page. 51-58

Journal Homepage : http://teknois.stikombinaniaga.ac.id/index.php/JBS

DOI Link : http://doi.org/10.36350/jbs.v11i1

2020, pp. 1-12, doi:10.36350/jbs.v10i1.75.

[14] Utari, Lis, and Ria Agustriani. "Penerapan Metode Simple Additive Weighting untuk Merekomendasikan Penentuan Supplier Bahan Baku Kertas." Teknois, vol. 9, no. 1, 16 May. 2019, pp. 43-52, doi:10.36350/jbs.v9i1.3. 